\title{
Watermelon Mosaic Virus Resistant Watermelon Breeding Lines WM-1, WM-2, WM-3, and WM-4
}

\author{
A. Graves Gillaspie, Jr. ${ }^{1}$, and Robert L. Jarret ${ }^{2}$ \\ U.S. Department of Agriculture, Agricultural Research Service, Plant Genetic \\ Resources Conservation Unit, Griffin, GA 30223-1797
}

\section{Additional index words. Citrullus lanatus}

The U.S. Dept. of Agriculture, Agricultural Research Service, announces the release of WM-1, WM-2, WM-3, and WM-4, watermelon mosaic virus 2 (WMV) resistant watermelon [Citrullus lanatus (Thunb.) Matsum \& Nakai] breeding lines. These lines are unique in that they exhibit a high level of resistance to infection by the FC- 1656 strain of WMV prevalent in Florida, and demonstrate resistance in the greenhouse to virus isolates from Arizona and Italy (PV-27 and PV-379, respectively, American Type Culture Collection, Rockville, Md.), California (company test strain, Peto Seed Co., Woodland, Calif.), Israel (strains K and $M$, Volcani Institute, Bet Dagan), and New York (strains NY-Rob-80 and NY-91, Cornell Univ., Geneva, N.Y.). In addition, susceptible plants demonstrate milder symptoms when infected with any of the virus strains tested than do standard susceptible lines. These lines were developed at the Plant Genetic Resources Conservation Unit, Griffin, $\mathrm{Ga}$.

\section{Origin}

WM-1, WM-2, WM-3, and WM-4 were selected from watermelon plant introductions (PIs) 189316, 189317, and 248178, and 'Egun', respectively. These plant materials originated in Africa (the first three from Zaire and the fourth from Nigeria). PIs 189316,189317 , and 248178 were obtained from the S-9 Citrullus germplasm collection in Griffin, Ga. (Jarret et al., 1990). Seed of 'Egun' was obtained from Auburn Univ.

Received for publication 15 July 1996 . Accepted for publication $10 \mathrm{Jan}$. 1997. Mention of a trademark or proprietary product does not constitute a guarantee or warranty of the product by the U.S. Dept. of Agriculture and does not imply its approval to the exclusion of other products that may also be available. The cost of publishing this paper was defrayed in part by the payment of page charges. Under postal regulations, this paper therefore must be hereby marked advertisement solely to indicate this fact. 'Research Plant Pathologist.

${ }^{2}$ Research Horticulturist.
All PIs were selected for their resistance and regenerative ability from among the 670 PIs previously evaluated in a series of greenhouse and field tests (beginning in 1989) for resistance to WMV (FC-1656) (Gillaspie and Wright, 1993, 1996). Greenhouse selections were obtained by mechanical inoculation of seedlings, selection [by enzyme-linked immunosorbent assay (ELISA) $10 \mathrm{~d}$ after the final inoculations], and selfing of the resistant plants (single seed descent). Selfed progeny (50-100 seeds each) were tested in the field for their resistance (Gillaspie and Wright, 1993) to the virus using controlled inoculated "spreader" rows, and resistant plants were further selected by ELISA and self-pollinated (15 plants each). An alternating series of greenhouse and field testing, selection, and selfing followed, and breeding was completed in 1993. WM-1 is the result of four, WM-2 five, and WM-3 three selfing generations. WM-4 is the result of five selfing generations followed by sib-mating. The resulting progenies of all four lines were screened for resistance to the seven additional isolates of WMV mentioned above in greenhouse tests and all were highly resistant.

Table 1. Response of watermelon lines WM-1, WM-2, WM-3, and WM-4 to watermelon mosaic virus under controlled inoculation conditions at Byron, $\mathrm{Ga}$.

\begin{tabular}{lcc}
\hline & \multicolumn{2}{c}{ Percent infection } \\
\cline { 2 - 3 } Line & 1992 & 1993 \\
\hline WM-1 & $0^{\mathrm{x}}$ & 0 \\
WM-2 & $15(10-20)^{y}$ & $19(0-50)$ \\
WM-3 & -- & $29(0-50)$ \\
WM-4 & $3(0-11)$ & 0 \\
Control $^{\mathrm{x}}$ & 90 & 95
\end{tabular}

${ }^{2}$ Forty seedlings of each line were planted in a randomized block design (10 seedlings/plot). Infection was determined by ELISA 4-6 weeks after spreader-row inoculation.

${ }^{y}$ Ranges of percentages of infection among plots. ×1992 susceptible control 'Baby Bush' watermelon, and 1993 control 'Scallop Early White Bush' squash. Infection was uniformly high throughout the plots, but only totals were recorded so variations in percentages are not known.
Description

Lines WM-1, WM-2, WM-3, and WM-4 were resistant to the F-1656 strain in comparison with the susceptible controls (Table 1). The 4-6 week ELISA results were considered the best indicator of resistance, since later infection did not seem to affect flowering or fruit production. In 1994, 30 seedlings of each line were tested against each of the eight WMV isolates mentioned above in a greenhouse at Griffin. The infection totals for WM1 were $17 \%$, WM-2 $12 \%$, WM-3 20\%, and WM-4 6\% (as determined by ELISA serology), while $90 \%$ of inoculated pumpkin control plants had virus symptoms. The resistance to WMV makes these lines valuable sources of germplasm for the development of virus-resistant watermelon cultivars.

All four lines are "egusi"-type Citrullus lanatus and are morphologically similar to the egusi melons described by Oyolu (1977). The seed kernels of egusi melons are a significant source of oil and protein in West Africa (Oyolu, 1997). The lines W-1 to W-4 are not of acceptable horticultural quality and thus are unsuitable for direct use as cultivars. The fruits are small, green, have bitter fruit pulp, and are of poor eating quality. However, their flowering, maturity, and seed production characteristics make them attractive sources of genes for virus resistance.

\section{Availability}

Seed is available, upon request, on a prorata basis to both public and private breeders. Requests should be addressed to R.L. Jarret, USDA, ARS, Plant Genetic Resources Conservation Unit, 1109 Experiment Street, Griffin, GA 30223-1797. Genetic material of this release will be deposited in the National Plant Germplasm System, where it will be available for research purposes. We request that appropriate recognition be made if this germplasm contributes to the development of a new breeding line or cultivar.

\section{Literature Cited}

Gillaspie, A.G., Jr., and J.M. Wright. 1993. Evaluation of Citrullus sp. germplasm for resistance to watermelon mosaic virus 2. Plant Dis. 77:352354.

Gillaspie, A.G., Jr., and J.M. Wright. 1996. Evaluation of Citrullus lanatus germplasm for resistance to watermelon mosaic virus 2 strains. Georgia Agr. Expt. Sta. Res. Rpt. 638.

Jarret, R.L., M. Spinks, G. Lovell, and A.G. Gillaspie. 1990. The S-9 plant germplasm collection at Griffin, Georgia. Diversity 6(2):23-25.

Oyolu, C. 1977. A quantitative and qualitative study of seed types in egusi (Colocynthis citrullus L.). Trop. Sci. 19:55-62. 